\title{
Tax change curtails UK university spin-offs
}

Jim Giles, London

The creation of spin-off companies at British universities has fallen dramatically over the past six months because of a change in the tax laws, Nature has established.

The country's top universities typically each launch five to ten new companies every year. But the four highest-ranked research institutions - University College London, Imperial College London and the universities of Oxford and Cambridge - have created just six spin-offs between them since last August, when the new rules came into force.

The spin-offs have dried up, university officials say, because the tax laws now require directors to pay hefty taxes on the estimated value of shares they hold in a company within a year of its foundation. The rule was meant to close a tax loophole used by wealthy business executives - but it has had the unintended effect of making scientists think twice about starting a business venture.

"The rules have had a devastating effect," says Tom Hockaday, executive director of Isis Innovation, the University of Oxford's technology-transfer company. "They're killing what they say they want to create."

Sue Sundstrom, director of life sciences at the University of Southampton's Centre for Enterprise and Innovation, says the tax bill is "completely insane" given that government ministers are always calling on universities to do more to create wealth.

The drought might ease soon, because

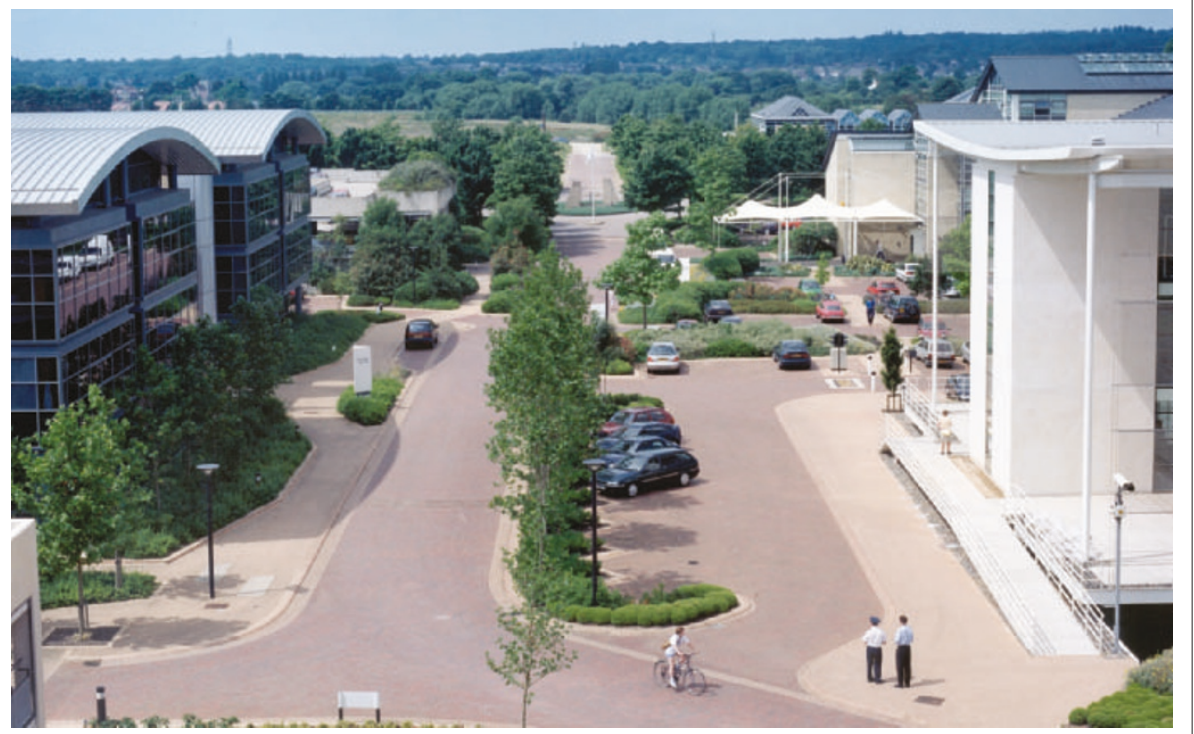

All quiet: attempts to close a tax loophole have slowed activity at places such as Oxford Science Park.

university technology-transfer officers and tax officials have agreed on a fresh interpretation of the law. But university officials caution that the revised interpretation will pose further problems for academics, and won't guarantee a full revival of spin-off activity.

In the revised arrangement, researchers can defer paying taxes by taking 'convertible preference' shares, which are subject to tax only at the time they are sold.

Technology-transfer officers say the change may encourage some academics to start launching companies again, but that it will expose them to even higher tax rates - of up to $48 \%$ - when they sell their shares.

A spokesman for the Inland Revenue, which helped draft the tax laws and negotiated the new arrangements with universities, said he recognized that there "had been a period of uncertainty" but that the revision should help universities meet commercial goals without creating tax problems for academics. He declined to comment on whether the higher tax burden would eventually be removed.

\section{AIDS drug price hike prompts calls for intervention}

Erika Check, Washington

The National Institutes of Health (NIH)

has been asked to step in and halt the spiralling cost of AIDS medications in the United States.

Under a 1980 technology-transfer law, the biomedical research agency can arrange for the generic production of pharmaceuticals whose invention was based on NIH-funded research, if the existing manufacturer will not provide the treatment on "reasonable terms".

In January, Essential Inventions, a non-profit group based in Washington DC, asked the NIH to invoke these 'march-in' rights with regard to the AIDS drug Norvir, made by Abbott Laboratories of Abbott Park, Illinois. Last December, Abbott raised the US price of Norvir treatment from $\$ 1.71$ to $\$ 8.57$ per day.

The NIH will discuss the request at a public hearing at its headquarters in Bethesda, Maryland, on 25 May. Abbott says the price rise is necessary because the drug is used in low doses, resulting in lower sales.
The request's supporters include Sherrod Brown (Democrat, Ohio), the senior minority member of the House of Representatives subcommittee, which oversees the NIH. "When a company raises the price of an essential medicine by $400 \%$, it gets anybody's attention," Brown says. Taxpayers pay for biomedical research, he says, "but we never invoke the mechanism that would bring prices down for the public".

The price increase angered AIDS activists because Norvir boosts other AIDS drugs called protease inhibitors - so all patients taking these are affected. The issue also coincides with a national argument over drug pricing in the run-up to November's elections.

That environment could make it hard for the NIH and its parent agency, the health department, to turn down the request. Health secretary Tommy Thompson "would have to say yes, it is reasonable for an invention to be ten times more expensive here than in other countries, even if US taxpayers funded it", says James Love, president of Essential Inventions.
Abbott says the price increase will not affect uninsured patients, who get the drug free, or others who get it under government programmes.

The company's supporters say that the Bayh-Dole Act, which contains the march-in clause, was not meant to control drug prices. Joseph Allen, president of the National Technology Transfer Center in Wheeling, West Virginia, and a former Senate staff member who worked on the act, says the phrase "reasonable terms" was not supposed to embrace price increases.

Love agrees that the question of what constitutes "reasonable terms" will be crucial to the outcome of the request. But he argues that Abbott is trying to quash competition by charging more to patients who use Norvir to boost other protease inhibitors, rather than using Abbott's own treatments, which incorporate the drug. "This is designed to prevent people from buying non-Abbott protease inhibitors," he says. "If this doesn't trigger the march-in, nothing does." 